\title{
Scheduled Announcements and Volatility Patterns: The Effects of Monetary Policy Committee Announcements on LIBOR and Short Sterling Futures and Options
}

\author{
Peng Sun ${ }^{P}$ and Charles Sutcliffe ${ }^{P}$
}

9 April 2001

P Accounting and Finance Division, School of Management, The University, Southampton SO17 1BJ, UK. email cms@ socsci.soton.ac.uk

The authors are grateful to Reuters and Money Market Services for the provision of the expectations data used in this study. 


\title{
Scheduled Announcements and Volatility Patterns: The Effects of Monetary Policy Committee Announcements on LIBOR and Short Sterling Futures and Options
}

\begin{abstract}
Both the UK spot and futures markets in short term interest rates are found to react strongly to surprises in the scheduled announcements of the repo rate and RPI. Therefore these announcements should also affect the market for options on short term interest rates. Because the repo rate and RPI announcements are scheduled, the options market can predict the days on which announcement shocks may hit, and build this information into its volatility expectations. A theoretical model is constructed where the volatility used in pricing options alters over time in a predictable non-linear manner that varies with contract maturity and the number of forthcoming announcements; but is independent of announcement content. The empirical results support the response coefficients of this theoretical model, and it is concluded that the UK spot, futures and options markets in short term interest rates are semi-strong efficient.
\end{abstract}

Keywords: Monetary Policy Committee, repo rate, RPI, LIBOR, interest rate futures, interest rate options, implied volatility, semi-strong efficiency, announcement effects

JEL: G14 
Scheduled Announcements and Volatility Patterns: The Effects of Monetary Policy

Committee Announcements on LIBOR and Short Sterling Futures and Options

The Monetary Policy Committee (MPC) of the Bank of England was set up on $6^{\text {th }}$ May 1997 and entrusted with setting UK interest rates (Budd, 1998). The MPC meets monthly, and at 12 noon on the scheduled day (usually the Thursday following the first Monday in each calendar month), announces the level at which they have set interest rates until their next meeting. The MPC has the policy objective of adjusting UK interest rates to achieve the target level of inflation specified by the Chancellor of the Exchequer. MPC decisions are a major instrument of the government's macroeconomic policy, and have an important influence on the UK economy.

Scheduled announcements (such as those of the MPC) have a different effect from unscheduled announcements on market volatility, and this is the first study to trace the impact of MPC interest rate announcements through the three markets: spot, futures and options. The main focus of this research is on the effect of MPC announcements on the anticipated volatility of interest rate futures contracts implied in the price of options on interest rate futures. This research is the first to model the effects of contract maturity on this relationship, and the first to allow for more than one outstanding scheduled announcement (which may be of several different types). It is demonstrated that implied volatility is only affected by the anticipated announcement day volatility, and not by the actual content of the announcement. It is also shown that movements in implied volatility (and hence options prices) are predictable, and that this is consistent with semi-strong market efficiency. Finally, the analysis provides a possible explanation for the volatility term structure.

In section 1 the effect of MPC and seven other macroeconomic announcements on spot interest rates (LIBOR) is studied, while in section 2, the impact of these announcements on the interest rate futures market is analysed. The two scheduled macroeconomic 
announcements identified in sections 1 and 2 as having a significant effect on spot and futures interest rates (the repo rate and the retail price index) are then used in section 3 to investigate the effect on the interest rate options market. A model is developed where the effect of a scheduled announcement on the options market is a non-linear function of option maturity, as well as the number of outstanding scheduled announcements and the volatility expected on their release. This model is then tested and found to be consistent with the data. It is also shown that the reaction of the options market is unaffected by the size of the announcement surprises. Finally, section 4 contains the conclusions.

\section{The Effect of Scheduled Announcements on Short Term Interest Rates}

The MPC sets the repo rate ${ }^{1}$ which is the interest rate implicit in the prices at which the Bank of England is prepared to buy assets from a bank and sell them back to the same bank about two weeks later. This rate sets the minimum cost of short term bank funds and, to the extent that any change in the repo rate is not absorbed by a change in the mark-up charged by banks to their customers, directly affects short term interest rates. Since the MPC meets once a month, their announcements determine the repo rate for the next month. In addition to a direct effect on short term interest rates, a change in the repo rate may also affect longer term interest rates via its effect on expectations of future short term rates.

This link in the transmission of monetary policy is examined by studying the effect of repo rate changes announced by the MPC on 3 month LIBOR rates for sterling deposits. Daily changes ${ }^{2}$ in LIBOR $\left(\Delta L_{t}\right)$ were regressed on a set of nine macroeconomic variables: unexpected increases in the repo rate $\left(U \Delta M P C_{t}^{+}\right)^{3}$, unexpected decreases in the repo rate $\left(U \Delta M P C_{t}^{-}\right)$, unexpected changes in the index of production $\left(U \Delta I P_{t}\right)$, unexpected changes in the retail price index $\left(U \Delta R P I_{t}\right)$, unexpected changes in the money supply $\left(U \Delta M 4_{t}\right)$, unexpected changes in consumer credit $\left(U \Delta C C_{t}\right)$, unexpected changes in earnings $\left(U \Delta E_{t}\right)$, unexpected changes in producer prices $\left(U \Delta P P_{t}\right)$, and unexpected changes in retail sales $\left(U \Delta R S_{t}\right)$. In addition, the first and second lags of the dependent variable were also 
included in the regression equation ${ }^{4}$. These scheduled macroeconomic announcements were chosen to include economic factors thought likely to affect LIBOR, and to minimise the inclusion of announcements that occur on the same day as other announcements included in the model.

The contributor banks input their rates for LIBOR between 11:00 am and 11:10 am, while the other macroeconomic variables are announced at 9:30 am. Therefore LIBOR should reflect any macroeconomic announcements made earlier in the morning. However, since the repo rate is announced at noon, this can only be reflected in the following day's LIBOR rate, and so the MPC variables $\left(U \Delta M P C_{t}^{+}, U \Delta M P C_{t}^{-}\right)$were lagged by one day. The estimated regression equation is:-

$$
\begin{aligned}
& \Delta \mathrm{L}_{\mathrm{t}}=\alpha+\beta_{1} \mathrm{U} \Delta \mathrm{MPC}_{\mathrm{t}-1}{ }^{+}+\beta_{2} \mathrm{U} \Delta \mathrm{MPC}_{\mathrm{t}-1}{ }^{-}+\beta_{3} \mathrm{U} \Delta \mathrm{IP}_{\mathrm{t}}+\beta_{4} \mathrm{U} \Delta \mathrm{RPI}_{\mathrm{t}}+\beta_{5} \mathrm{U} \Delta \mathrm{M}_{\mathrm{t}}+ \\
& \beta_{6} \mathrm{U} \Delta \mathrm{CC}_{\mathrm{t}}+\beta_{7} \mathrm{U} \Delta \mathrm{E}_{\mathrm{t}}+\beta_{8} \mathrm{U} \Delta \mathrm{PP}_{\mathrm{t}}+\beta_{9} \mathrm{U} \Delta \mathrm{RS}_{\mathrm{t}}+\beta_{10} \mathrm{U} \Delta \mathrm{L}_{\mathrm{t}-1}+\beta_{11} \mathrm{U} \Delta \mathrm{L}_{\mathrm{t}-2}+\epsilon_{\mathrm{t}} \\
& \text { where } \sigma_{\epsilon(\mathrm{t})}^{2}=\left\{\alpha_{0}+\alpha_{1} \epsilon_{\mathrm{t}-1}^{2}+\alpha_{2} \sigma_{\epsilon(\mathrm{t}-1)}^{2}\right\}\left\{1+\alpha_{3} \mathrm{D}_{1, \mathrm{t}-1}\right\}
\end{aligned}
$$

where $D_{1, t-1}$ is a dummy variable that takes the value of unity one day after an MPC announcement. A multiplicative GARCH $(1,1)$ estimation procedure was adopted to model the periodic breaks in the volatility structure caused by the monthly MPC announcements, (Li and Engle, 1998, and Jones, Lamont and Lumsdaine, 1998). The appropriateness of using this regime-switching specification will be examined by testing the significance of $\alpha_{3}$.

Assuming that a change in the repo rate causes the same change in all the rates at the short end of the yield curve ${ }^{5}$, an unexpected change in the repo rate is predicted to lead to a similar effect on LIBOR, i.e. $\beta_{1}=\beta_{2}=1$ (hypothesis 1). Using the LM test (Engle, 1982), the error term of equation (1) was found to be $\mathrm{ARCH}$, while the Jarque-Bera test statistic indicated non-normality at an extremely high level of significance. Therefore equation (1) was estimated using the quasi-maximum likelihood techniques of Bollerslev and 
Woodridge (1992). This estimator gives consistent estimates and valid standard errors for

GARCH models with lagged dependent variables and non-normal disturbances. The results for equation (1) are shown in table $1^{6}$.

\title{
Coefficient z statistic Probabilit
}

\begin{tabular}{lcrc} 
Constant & & & \multicolumn{1}{c}{$\mathbf{y}$} \\
$\mathrm{U} \Delta \mathrm{MPC}_{\mathrm{t}-1}{ }^{+}$ & 0.000281 & 0.361 & 0.7184 \\
$\mathrm{U} \Delta \mathrm{MPC}_{\mathrm{t}-1}{ }^{-}$ & $0.680228^{* *}$ & 5.413 & 0.0000 \\
$\mathrm{U} \Delta \mathrm{RPI}_{\mathrm{t}}$ & $0.479339^{* *}$ & 11.414 & 0.0000 \\
$\mathrm{U} \Delta \mathrm{IP}_{\mathrm{t}}$ & $0.090992^{* *}$ & 3.319 & 0.0010 \\
$\mathrm{U} \Delta \mathrm{M}_{\mathrm{t}}$ & $0.021237^{*}$ & 2.080 & 0.0375 \\
$\mathrm{U} \Delta \mathrm{CC}_{\mathrm{t}}$ & -0.002888 & -0.618 & 0.5363 \\
$\mathrm{U} \Delta \mathrm{E}_{\mathrm{t}}$ & -0.009633 & -1.049 & 0.2940 \\
$\mathrm{U} \Delta \mathrm{PP}_{\mathrm{t}}$ & 0.024234 & 1.089 & 0.2761 \\
$\mathrm{U} \Delta \mathrm{RS}_{\mathrm{t}}$ & -0.026905 & -1.163 & 0.2449 \\
$\mathrm{U} \Delta \mathrm{L}_{\mathrm{t}-1}$ & 0.009165 & 1.373 & 0.1699 \\
$\mathrm{U} \Delta \mathrm{L}_{\mathrm{t}-2} \quad$ Conditional Variance Equation & $(\mathrm{GARCH}(1,1))$ \\
$\mathrm{Constant}\left(\alpha_{0}\right)$ & $0.000273^{* *}$ & 7.029 & 0.0000 \\
$\mathrm{ARCH}\left(\alpha_{1}\right)$ & $0.266473^{*}$ & 2.506 & 0.0122 \\
$\mathrm{GARCH}\left(\alpha_{2}\right)$ & 0.047739 & 0.772 & 0.4399 \\
Multiplicative $\left(\alpha_{3}\right)$ & $7.906363^{*}$ & 2.227 & 0.0260
\end{tabular}

\section{Table 1: Effect of Unexpected Changes in Macro Variables on LIBOR}

\begin{abstract}
Equation (1) was estimated using the quasi-maximum likelihood techniques of Bollerslev and Woodridge (1992). The dependent variable is the change in LIBOR $\left(\Delta L_{t}\right)$. The explanatory variables are the unexpected increases in the repo rate $\left(U \Delta M P C_{t}^{+}\right)$, unexpected decreases in the repo rate $\left(U \Delta M P C_{t}^{-}\right)$, unexpected changes in the index of production $\left(U \Delta I P_{t}\right)$, unexpected changes in the retail price index $\left(U \Delta R P I_{t}\right)$, unexpected changes in the money supply $\left(U \Delta M 4_{t}\right)$, unexpected changes in consumer credit $\left(U \Delta C C_{t}\right)$, unexpected changes in earnings $\left(U \Delta E_{t}\right)$, unexpected changes in producer prices $\left(U \Delta P P_{t}\right)$, unexpected changes in retail sales $\left(U \Delta R S_{t}\right)$, and lagged values of the dependent variable. $* *=$ significant at the $1 \%$ level, $*=$ significant at the $5 \%$ level. Number of observations $=675$. Adjusted $\mathrm{R}^{2}=0.554$, the $\mathrm{Q}$-statistics are insignificant at all lags from 1 to 36 , Jarque-Bera $=387$.
\end{abstract}

The results in table 1 show that the constant term $\left(\alpha_{0}\right)$ is close to zero, implying that if there is no unexpected change in any explanatory variable, there is no change in LIBOR. The significant values of $\alpha_{1}$ and $\alpha_{3}$ indicate a strong multiplicative ARCH effect, while the GARCH term is not significant. On MPC announcement days volatility is nine times (i.e. $1+\alpha_{3}$ ) larger than otherwise. Changes in LIBOR are largely caused by unexpected changes in the repo rate set by the MPC. Unexpected increases in the repo rate have a 
larger positive effect on LIBOR than do unexpected decreases, and this difference is significant at the $1 \%$ level. This asymmetry could be due to banks quickly passing on an increase in their costs, but acting more slowly in passing on a reduction in their costs. The other significant explanatory variables (index of production, RPI and the lagged values of changes in LIBOR) have much smaller coefficients. The positive relationship between the RPI and LIBOR is consistent with a link between inflation and interest rates, while the positive effect of the index of production accords with higher levels of production increasing the demand for funds.

The values of both $\beta_{1}$ and $\beta_{2}$ are significantly smaller than one, and so hypothesis 1 is rejected. The average effect of an MPC announcement on LIBOR is a bit over half the size of the surprise, and this accords with the empirical findings of Kuttner (2000), who found that an unexpected change of $1 \%$ in the Federal Open Market Committee (FOMC) target rate leads to a $0.504 \%$ change in the US 3-month Treasury bill rate. Bomfim and Reinhart (2000) found an even lower response of $0.25 \%$ for unexpected changes in the FOMC target rate.

There are two possible explanations for this apparent under-response by LIBOR. First, when an expected change in the repo rate does not occur in the current MPC announcement, it is likely that the predicted change is now expected to occur in a subsequent MPC announcement. Since LIBOR relates to a 3 month period, such a situation results in LIBOR changing by less than the surprise in the MPC announcement ${ }^{7}$. A similar argument applies when a change in the repo rate occurs earlier than expected. Second, the expectations data used in the analysis may not correctly quantify market expectations at noon on the day before the announcement. This may be because the expectations survey is carried out 7 days before the announcement and market expectations become more accurate between then and the day before the announcement; or because there is sampling error in the expectations survey. 


\section{The Effect of Scheduled Announcements on Short Sterling Futures Prices}

There have been a number of previous studies of the effect of spot interest rates on interest rate futures prices. Buckle, et. al. (1998) found Short Sterling futures had a higher volatility between 9:50 am and 9:55 am on days when unscheduled changes in the Bank of England base rate ${ }^{8}$ were announced. Slovin, Sushka and Waller (1994) found that the announcement of changes in the prime interest rate charged by US banks immediately affected the price of US treasury bill futures. While these announcements were unscheduled, they show the price sensitivity of futures on government interest rates to changes in spot interest rates. Li and Engle (1998) found that the unexpected component of scheduled macroeconomic announcements affects returns and the volatility of returns on US Treasury bond futures.

LIFFE trades Short Sterling futures whose underlying asset is LIBOR for 3 month Sterling deposits. The near futures contracts have a maturity of 1,2 or 3 months, and so the current futures price reflects expectations of the spot LIBOR rate for 3 months, starting in 1,2 or 3 months time, i.e. the forward rate. News announcements directly affect both the spot rate and the forward rate. In addition, the spot LIBOR rate is linked to the LIBOR forward rate via arbitrage ${ }^{9,10}$. Since LIBOR and Sterling futures prices are determined by a similar information set, daily changes in the futures price $\left(\Delta F_{t}\right)$ were regressed on the same set of explanatory variables that was used for LIBOR (excluding the lagged values of the dependent variable $)^{11}$. Since the futures price observations are made after the noon announcements of the repo rate, there is no need to lag the MPC announcements.

$$
\begin{aligned}
& \Delta \mathrm{F}_{\mathrm{t}}=\alpha+\beta_{1} \mathrm{U} \Delta \mathrm{MPC}_{\mathrm{t}}^{+}+\beta_{2} \mathrm{U} \Delta \mathrm{MPC}_{\mathrm{t}}^{-}+\beta_{3} \mathrm{U} \Delta \mathrm{IP}_{\mathrm{t}}+\beta_{4} \mathrm{U} \Delta \mathrm{RPI}_{\mathrm{t}}+\beta_{5} \mathrm{U} \Delta \mathrm{M} 4_{\mathrm{t}}+\beta_{6} \mathrm{U} \Delta \mathrm{CC}_{\mathrm{t}} \\
& +\beta_{7} \mathrm{U} \Delta \mathrm{E}_{\mathrm{t}}+\beta_{8} \mathrm{U} \Delta \mathrm{PP}_{\mathrm{t}}+\beta_{9} \mathrm{U} \Delta \mathrm{RS}_{\mathrm{t}}+\epsilon_{\mathrm{t}} \\
& \text { where } \sigma_{\epsilon(\mathrm{t})}^{2}=\left\{\alpha_{0}+\alpha_{1} \epsilon_{\mathrm{t}-1}^{2}+\alpha_{2} \sigma_{\epsilon(\mathrm{t}-1)}^{2}\right\}\left\{1+\alpha_{3} \mathrm{D}_{1, \mathrm{t}}\right\}
\end{aligned}
$$

An unexpected change in the repo rate is again predicted to lead to a similar effect on the rate of return implicit in the price of Short Sterling futures, i.e. $\beta_{1}=\beta_{2}=-1$ (hypothesis 
$2)^{12}$. Using the Engle (1982) LM test, the error terms of this equation were found to be $\mathrm{ARCH}$ at the $2.4 \%$ significance level, while the errors were highly non-normal. Therefore, as for LIBOR, the quasi-maximum likelihood techniques of Bollerslev and Woodridge (1992) were used. The results for equation (2) are shown in table $2^{13}$.

\title{
Coefficient z statistic Probabilit
}

\begin{tabular}{lccc} 
& & & $\mathbf{y}$ \\
Constant & -0.000240 & -0.192 & 0.8474 \\
$\mathrm{U} \Delta \mathrm{MPC}_{\mathrm{t}}^{+}$ & $-0.894761^{* *}$ & -6.513 & 0.0000 \\
$\mathrm{U} \Delta \mathrm{MPC}_{\mathrm{t}}^{-}$ & $-0.544276^{* *}$ & -4.781 & 0.0000 \\
$\mathrm{U} \Delta \mathrm{RPI}_{\mathrm{t}}$ & $-0.218661^{* *}$ & -2.620 & 0.0088 \\
$\mathrm{U} \Delta \mathrm{IP}_{\mathrm{t}}$ & -0.015144 & -0.912 & 0.3618 \\
$\mathrm{U} \Delta \mathrm{M}_{\mathrm{t}}$ & 0.004941 & 0.678 & 0.4981 \\
$\mathrm{U} \Delta \mathrm{CC}_{\mathrm{t}}$ & $-0.042974^{*}$ & -2.268 & 0.0233 \\
$\mathrm{U} \Delta \mathrm{E}_{\mathrm{t}}$ & $-0.066432^{*}$ & -2.260 & 0.0238 \\
$\mathrm{U} \Delta \mathrm{PP}_{\mathrm{t}}$ & 0.018925 & 0.527 & 0.5976 \\
$\mathrm{U} \Delta \mathrm{RS}_{\mathrm{t}}$ & $-0.023267^{*}$ & -2.033 & 0.0421 \\
\multicolumn{4}{c}{ Conditional Variance Equation } \\
Constant $\left(\alpha_{0}\right)$ & $0.000994^{* *}$ & 9.646 & 0.0000 \\
ARCH $\left(\alpha_{1}\right)$ & $0.130588^{* *}$ & 2.739 & 0.0062 \\
GARCH $\left(\alpha_{2}\right)$ & -0.065886 & -1.155 & 0.2481 \\
Multiplicative $\left(\alpha_{3}\right)$ & $4.538621^{* *}$ & 2.977 & 0.0029
\end{tabular}

Table 2: Effect of Unexpected Changes in Macro Variables on Short Sterling Futures

\begin{abstract}
Equation (2) was estimated using the quasi-maximum likelihood techniques of Bollerslev and Woodridge (1992). The dependent variable is the change in the price of Short Sterling futures LIBOR $\left(\Delta F_{t}\right)$. The explanatory variables are the unexpected increases in the repo rate $\left(U \Delta M P C_{t}^{+}\right)$, unexpected decreases in the repo rate $\left(U \Delta M P C_{t}^{-}\right)$, unexpected changes in the index of production $\left(U \Delta I P_{t}\right)$, unexpected changes in the retail price index $\left(U \Delta R P I_{t}\right)$, unexpected changes in the money supply $\left(U \Delta M 4_{t}\right)$, unexpected changes in consumer credit $\left(U \Delta C C_{t}\right)$, unexpected changes in earnings $\left(U \Delta E_{t}\right)$, unexpected changes in producer prices $\left(U \Delta P P_{t}\right)$, unexpected changes in retail sales $\left(U \Delta R S_{t}\right)$, and lagged values of the dependent variable. $* *=$ significant at the $1 \%$ level, $*=$ significant at the $5 \%$ level. Number of observations $=675$. Adjusted $\mathrm{R}^{2}=0.295$, the $\mathrm{Q}$-statistics are insignificant at all lags from 1 to 36 , Jarque-Bera $=15.0$.
\end{abstract}

Table 2 shows that, as for LIBOR, the constant term $\left(\alpha_{0}\right)$ is close to zero, implying that if there is no unexpected change in any explanatory variable, there is no change in the price of Short Sterling futures. There is again a strong multiplicative ARCH effect in the errors, and the volatility on the day of an MPC announcement is 5.5 times larger than otherwise. The main cause of changes in Short Sterling futures prices is unexpected MPC 
announcements. Allowing for the sign change, the coefficients for positive and negative MPC surprises are similar to those found above for LIBOR, with positive MPC announcements having a bigger effect than negative announcements in each case. Unexpected changes in the RPI again have a significant effect (with the sign reversed), and the magnitude of this effect has more than doubled. This relationship is consistent with a positive link between inflation and interest rates. Unexpected changes in earnings, consumer credit and retail sales, all of which are associated with a more buoyant economy, have a small but significant effect.

The coefficient for positive MPC surprises is significantly different from the coefficient for negative surprises, but not significantly different from one; while that for negative MPC surprises is significantly below one. Thus, there is again an asymmetric response to MPC surprises, and hypothesis 2 is rejected for negative surprises, but accepted for positive surprises.

Overall, the empirical results for LIBOR and Short Sterling futures clearly indicate that the most powerful influence on each is unexpected changes in the repo rate announced by the MPC; with positive MPC surprises having a larger effect than negative MPC surprises. Apart from positive surprises on Short Sterling futures, the effect of surprises in MPC announcements on LIBOR and Short Sterling futures is less than one. This may be because the change in the repo rate occurred earlier or later than expected, or because the expectations data used in the analysis does not correctly quantify market expectations at noon on the day before the announcement. In addition, both LIBOR and Short Sterling futures are also affected by unexpected changes in the RPI, while LIBOR is affected by unexpected changes in the index of production, and Short Sterling futures are affected by unexpected changes in earnings, consumer credit and retail sales.

\section{The Effects of Scheduled Announcements on Short Sterling Options}

As well as affecting the spot and futures markets, announcements also affect the price of 
options written on the spot asset concerned. The volatility of the underlying asset is a major determinant of the options price, with increases in volatility leading to an increase in the price of both call and put options. Therefore, options prices can be used to study the effect of announcements on spot volatility using the volatilities implied by the options price.

Previous empirical studies have found that a wide variety of announcements affect the volatility implied in options prices. Some of these studies have analysed various scheduled announcements: twelve macroeconomic announcements (Ederington and Lee, 1996), three macroeconomic announcements (Li \& Engle, 1998), company earnings (Patell \& Wolfson, 1979, 1981, Donders \& Vorst, 1996, Copeland, Poon \& Stapleton, 2000), the balance of trade (Madura \& Tucker, 1992), the money supply (Bailey, 1988), a general election (Gemmill, 1992) and interest rate changes (Bomfim \& Reinhart, 2000). Other studies have looked at the effects of unscheduled announcements on implied volatility: ten major news announcements (Cornell, 1978), takeovers (Barone-Adesi, Brown \& Harlow, 1994), mergers (Jayaraman et al, 1991, Levy \& Yoder, 1993), interest rate changes (French \& Fraser, 1986), the effect of the Louvre Accord on volatility in currency markets (Tucker \& Madura, 1991), central bank intervention in the foreign exchange market (Bonser-Neal, 1996, Bonser-Neal \& Tanner, 1996) and dividend increases (Jayaraman \& Shastri, 1993). Finally, a few studies have looked at the announcement (unscheduled) and the ex-date (scheduled) effects of stock splits (French \& Dubofsky, 1986, Klein \& Peterson, 1988, Sheikh, 1989).

This section examines the effect of scheduled announcements on the implied volatility of options on Short Sterling futures. The option pricing model used to compute the implied volatilities is presented; followed by a discussion of the equivalence between the implied volatility and the average anticipated volatility over the remaining life of the option. After an intuitive statement of the relationship between time to expiry and anticipated volatility, a mathematical approach is used to derive this relationship. Finally, this theoretical 
relationship is tested by fitting it to daily data for Short Sterling options for 1997-1999. In contrast to some earlier papers (e.g. Bailey, 1988, Bomfim \& Reinhart, 2000 and Madura \& Tucker, 1992), the model does not use the size of the actual or surprise announcement to explain movements in implied volatility; and the validity of this approach is also tested.

\section{A. Option Pricing Model}

LIFFE, which uses futures-style margining for all its options contracts, trades American style options on Short Sterling futures. While these options are American rather than European style, this is of no consequence because, as Chen and Scott (1993) have shown, it is never optimal to exercise early an American style option on an interest rate future with futures-style margining. Therefore these options can be priced as though they are European style. While there are a number of possible pricing models, one of the most popular models for pricing options on futures is the Black (1976) model. The Black model can be modified for pricing options on interest rate futures to allow for futures-style margining and the convention that Short Sterling futures prices are quoted as deviations from 100. This model is:-

$$
\begin{gathered}
C_{i}=(100-K) N\left(\sigma_{i} \sqrt{t}-d_{i}\right)-\left(100-F_{i}\right) N\left(-d_{i}\right) \\
\text { where } d_{i}=\left[\ln \left(\left(100-F_{i}\right) /(100-K)\right)+0.5 \sigma_{i}^{2} t\right] / \sigma_{i} \sqrt{t}
\end{gathered}
$$

$C_{i}$ is the current price of the call option, $F_{i}$ is the current price of Short Sterling futures, $K$ is the exercise (or strike) price, $t$ is the time to expiry in years, $\sigma_{\mathrm{i}}$ is the standard deviation of the annualized yield on a futures contract (i.e. the annualized standard deviation of $\left.\ln \left[\left(100-F_{t}\right) /\left(100-F_{t-1}\right)\right]\right)$ and $N\left(d_{i}\right)$ is the probability that a standardised normally distributed random variable is less than or equal to $d_{\mathrm{i}}$.

This option pricing model can be used to compute the volatility implied by any call price. Rather than use a single strike price, the implied volatilities were computed using the 
Black model as the equally weighted average of the implied volatilities for the put and call options nearest to the money. Corrado and Miller (1996) argue that this way of computing implied volatilities performs as well as, or better than, any other method. The implied volatilities were computed using trading days, as suggested by French (1984), rather than calendar days.

\section{B. Average Anticipated Volatility}

The Black-Scholes (1973) and Black (1976) option pricing models assume that the volatility of the underlying asset is constant over time, which is not the case when there are scheduled price-sensitive announcements. As shown in the results above for LIBOR and Short Sterling futures, volatility is significantly higher on days with MPC announcements ( $\alpha_{3}$ is significant); while in the analysis below it is argued that scheduled announcements induce deterministic patterns into the average anticipated volatility. However, Merton (1973) argued that, if the anticipated variance of returns on the underlying asset is a deterministic function of a known variable (e.g. time), the BlackScholes (1973) (and Black, 1976) models remain valid, and the variance implied by the options price is equal to the average anticipated variance over the remaining life of the option $^{14} 15$.

In addition to a deterministic pattern, it is likely that the volatility of the underlying asset has an additional stochastic component. This may be because the content of the scheduled announcements is unpredictable, or because there are unscheduled announcements. If volatility is stochastic, the implied volatility computed using the Black-Scholes (1973) model tends to understate the true average anticipated volatility until expiry for at-themoney options, and this effect increases in size as the time to expiry lengthens, Hull and White (1987). However, as Hull and White have shown, these biases appear to be small (e.g. under 2\%). In addition, since the empirical analysis below uses the proportionate change in volatility, and all the volatilities are biased in the same direction; any such bias in measuring volatility levels will tend to cancel out. Furthermore, Heynen, Kemna \& 
Vorst (1992) show that if volatility follows a mean reverting, GARCH or EGARCH process, the Black-Scholes implied volatility for at-the-money options is a very accurate approximation to the average anticipated volatility.

\section{The Theoretical Effects of Scheduled Announcements on Volatility}

Consideration will now be given to the effect of scheduled announcements on the average anticipated volatility. Given the equivalence of the volatility implied by solving equation (3) and the average anticipated volatility during the remaining life of the option, the effects of scheduled announcements on the average anticipated volatility also apply to implied volatility. As shown in sections 1 and 2, some macroeconomic announcements (principally MPC and RPI) are important determinants of LIBOR and the price of Short Sterling futures. It was also found that the volatility of LIBOR and Short Sterling futures prices is higher on announcement than non-announcement days. In consequence, the average anticipated volatility until expiry for Short Sterling futures must allow for the increase in volatility from scheduled macroeconomic announcements.

Each day the average anticipated volatility for the remaining life of the option is computed over one less day. When the excluded day is an announcement day, the average anticipated volatility over the remaining life of the option tends to drop. However, when the excluded day is a non-announcement day, and there will be a scheduled announcement before expiry, the average anticipated volatility rises. When there are many days to expiry, the exclusion of a single day from computing the average anticipated volatility until expiry has a fairly small effect. However, when expiry is only a few days away, dropping a day has a much larger effect because the averaging is over far fewer days. After the last scheduled announcement before expiry, the average anticipated volatility is unaffected by the exclusion of the remaining non-announcement days because they all have the same anticipated volatility. The pattern of movements in implied volatility produced by these arguments is illustrated in figure 1. 


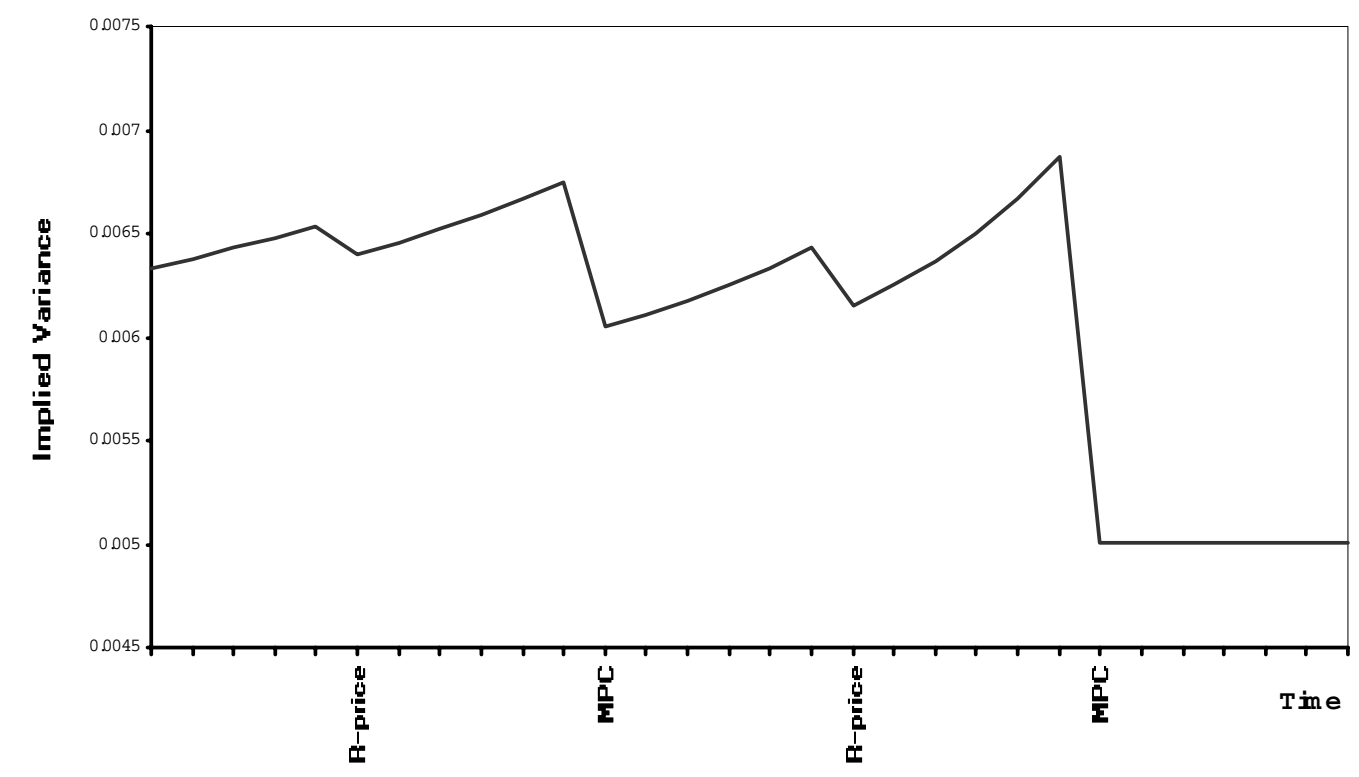

Figure 1: Effects of Two Types of Scheduled Announcement on Implied Volatility

The figure shows 30 days in the life of an option contract, and covers two MPC and two RPI announcements that are six days apart ${ }^{16}$. The anticipated volatility drops by a greater amount on MPC announcement days than on RPI announcement days, and by a greater amount when expiration is closer. Volatility rises in a non-linear manner on non-announcement days when there is a subsequent announcement, and does not change when there are no subsequent announcements.

The macroeconomic announcements may also alter expectations of volatility on subsequent days before expiry, leading to an upward or downward revision of the average anticipated volatility until expiry. For example, using data from an expectations survey, Madura and Tucker (1992) found that expectations of subsequent volatility are revised upwards when the scheduled announcement constitutes a large surprise. However, the investigation in section 3.E supports the view that the level of anticipated volatility from various types of scheduled UK announcement is constant over time and not influenced in a predictable way by announcement surprises. Finally, there is no need to allow for the effects of unscheduled announcements on implied volatility because, since they are unanticipated, they cannot be reflected in the average anticipated volatility. 
The above arguments will now be presented in a more formal way, leading to a regression equation which can be used to test the model. Both the spot and futures markets have been shown to be affected by MPC and RPI announcements, and these announcements have a much bigger effect on each of these markets than any of the other scheduled announcements. Therefore, the theory will be developed and tested for two scheduled announcements, although it could be generalised to $n$ announcements in a straightforward manner. If the expected volatility of the underlying asset for days on which there is an MPC announcement is $\sigma_{a}^{2}$, that for other scheduled announcement (e.g. RPI) days is $\sigma_{b}^{2}$, that for non-announcement days is ${\sigma_{n a}}^{2}$, and assuming that these expected volatilities of the underlying asset are not altered in a consistent manner by actual announcements ${ }^{17}$, then on day $t$ the average anticipated volatility between now and expiry is:-

$$
\sigma_{\mathrm{t}}^{2}=\left(\mathrm{m}_{\mathrm{t}}{\sigma_{\mathrm{na}}^{2}}^{2}+\mathrm{k}_{\mathrm{t}}{\sigma_{\mathrm{b}}^{2}}^{2}+\mathrm{n}_{\mathrm{t}}{\sigma_{\mathrm{a}}^{2}}^{2}\right) / \mathrm{T}_{\mathrm{t}}
$$

where $m_{t}$ is the remaining number of non-announcement days before expiry, $n_{\mathrm{t}}$ is the remaining number of MPC announcements, $k_{t}$ is the number of other price sensitive scheduled announcements, $T_{t}$ is the number of days to expiry $\left(k_{t}+m_{t}+n_{t} \equiv T_{t}\right)^{18}$, and $\sigma_{t}^{2}$ is the average anticipated volatility until expiry, given the information available on day $t$. If there is no scheduled announcement on day $t$, then:-

$$
\sigma_{\mathrm{t}-1}^{2}=\left(\left(\mathrm{m}_{\mathrm{t}}+1\right) \sigma_{\mathrm{na}}^{2}+\mathrm{k}_{\mathrm{t}}{\sigma_{\mathrm{b}}}^{2}+\mathrm{n}_{\mathrm{t}} \sigma_{\mathrm{a}}^{2}\right) /\left(\mathrm{T}_{\mathrm{t}}+1\right)
$$

and so the proportionate change in the average anticipated volatility on day $t$ is:-

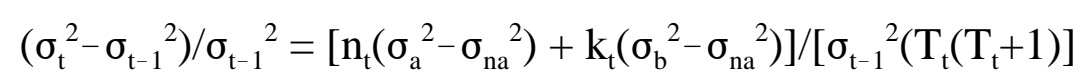

If there is a scheduled MPC announcement on day $t$ then:-

$$
\sigma_{\mathrm{t}-1}^{2}=\left(\mathrm{m}_{\mathrm{t}}{\sigma_{\mathrm{na}}}^{2}+\mathrm{k}_{\mathrm{t}}{\sigma_{\mathrm{b}}}^{2}+\left(\mathrm{n}_{\mathrm{t}}+1\right) \sigma_{\mathrm{a}}{ }^{2}\right) /\left(\mathrm{T}_{\mathrm{t}}+1\right)
$$


and so the proportionate change in the average anticipated volatility on day $t$ is:-

$$
\left(\sigma_{\mathrm{t}}^{2}-{\sigma_{\mathrm{t}-1}}^{2}\right) / \sigma_{\mathrm{t}-1}{ }^{2}=\left[\mathrm{m}_{\mathrm{t}}\left({\sigma_{\mathrm{na}}}^{2}-\sigma_{\mathrm{a}}{ }^{2}\right)+\mathrm{k}_{\mathrm{t}}\left(\sigma_{\mathrm{b}}{ }^{2}-\sigma_{\mathrm{a}}{ }^{2}\right)\right] /\left[\sigma_{\mathrm{t}-1}{ }^{2}\left(\mathrm{~T}_{\mathrm{t}}\left(\mathrm{T}_{\mathrm{t}}+1\right)\right]\right.
$$

If there is another type of scheduled announcement on day $t$, then:-

$$
\sigma_{\mathrm{t}-1}^{2}=\left(\mathrm{m}_{\mathrm{t}} \sigma_{\mathrm{na}}^{2}+\left(\mathrm{k}_{\mathrm{t}}+1\right) \sigma_{\mathrm{b}}^{2}+\mathrm{n}_{\mathrm{t}} \sigma_{\mathrm{a}}^{2}\right) /\left(\mathrm{T}_{\mathrm{t}}+1\right)
$$

and so the proportionate change in the average anticipated volatility on day $t$ is:-

$$
\left(\sigma_{\mathrm{t}}^{2}-{\sigma_{\mathrm{t}-1}}^{2}\right) / \sigma_{\mathrm{t}-1}{ }^{2}=\left[\mathrm{m}_{\mathrm{t}}\left({\sigma_{\mathrm{na}}}^{2}-{\sigma_{\mathrm{b}}}^{2}\right)+\mathrm{n}_{\mathrm{t}}\left(\sigma_{\mathrm{a}}{ }^{2}-{\sigma_{\mathrm{b}}}^{2}\right)\right] /\left[\sigma_{\mathrm{t}-1}{ }^{2}\left(\mathrm{~T}_{\mathrm{t}}\left(\mathrm{T}_{\mathrm{t}}+1\right)\right]\right.
$$

Letting $\mathrm{x}=\left(\sigma_{\mathrm{a}}{ }^{2}-{\sigma_{\mathrm{na}}}^{2}\right), \mathrm{y}=\left({\sigma_{\mathrm{b}}}^{2}-{\sigma_{\mathrm{na}}}^{2}\right)$ and $\mathrm{z}=\left(\sigma_{\mathrm{a}}{ }^{2}-{\sigma_{\mathrm{b}}}^{2}\right)$, equations (6), (8) and (10) give:-

$$
\left(\sigma_{\mathrm{t}}^{2}-{\sigma_{\mathrm{t}-1}}^{2}\right) / \sigma_{\mathrm{t}-1}{ }^{2}=\left[\left\{\mathrm{xn}_{\mathrm{t}}+\mathrm{yk}_{\mathrm{t}}\right\} \mathrm{D}_{3 \mathrm{t}}-\left\{\mathrm{m}_{\mathrm{t}} \mathrm{x}+\mathrm{k}_{\mathrm{t}} \mathrm{z}\right\} \mathrm{D}_{1 \mathrm{t}}+\left\{\mathrm{n}_{\mathrm{t}} \mathrm{z}-\mathrm{m}_{\mathrm{t}} \mathrm{y}\right\} \mathrm{D}_{2 \mathrm{t}}\right] /\left[\sigma_{\mathrm{t}-1}{ }^{2}\left(\mathrm{~T}_{\mathrm{t}}\left(\mathrm{T}_{\mathrm{t}}+1\right)\right]\right.
$$

where $D_{1 p}, D_{2 t}$ and $D_{3 t}$ are zero-one dummies indicating MPC, other scheduled announcements and no announcements respectively. The relationships between the dummy variables and the dependent variable are non-linear and time varying. For example, when the time to expiry is long, $T_{t}\left(T_{t}+1\right)$ is large and the effect of an announcement on volatility is small.

The coefficients in equation (11) show that when a non-announcement day is dropped for any given $T_{t}$, the absolute size of the effect is bigger when there are more scheduled announcements $\left(n_{t}+k_{t}\right)$ to come. If there are no subsequent scheduled announcements $\left(n_{t}+k_{t}=0\right)$, the effect is zero. The total effect of dropping a non-announcement day on the proportionate change in the average anticipated volatility is given by $\left(x n_{t}\right.$ $\left.+y k_{t}\right) /\left[\sigma_{t-1}^{2}\left(T_{t}\left(T_{t}+1\right)\right]\right.$. Because both $x$ and $y$ are positive, average anticipated volatility increases when there is no scheduled announcement, (hypothesis 3). 
The total effect of dropping an MPC announcement day on the proportionate change in the average anticipated volatility is given by $-\left(x m_{t}+z k_{t}\right) /\left[\sigma_{t-1}{ }^{2}\left(T_{t}\left(T_{t}+1\right)\right]\right.$. As $\sigma_{n a}{ }^{2}<\sigma_{a}{ }^{2}, x$ should be positive. The coefficient $z$ can be positive or negative; but will probably be absolutely smaller than $x$. In consequence, the effect of dropping an MPC announcement will probably be negative; although it could be positive if $z$ is strongly negative and $k_{t}$ is $\operatorname{large} e^{19}$. Due to the incorporation of more than one type of scheduled announcement, this result conflicts with the conclusion of previous studies that this effect is unambiguously negative. Hypothesis 4 is that MPC announcements have a negative effect on the volatility implied by options prices.

Finally, the total effect of dropping the other type of scheduled announcement on the proportionate change in the average anticipated volatility is $\left(n_{t} z-m_{t} y\right) /\left[\sigma_{t-1}^{2}\left(T_{t}\left(T_{t}+1\right)\right]\right.$, and this will tend to be negative, although it could be positive if $n_{t}$ and $z$ are large. Hypothesis 5 is that other announcements have a negative effect on the volatility implied by options prices.

\section{Empirical Testing of the Model}

The model developed above of the effects of scheduled announcements on volatility was tested using daily data for call and put options on Short Sterling futures for May 1997 to December 1999. Fifteen trading days before expiry, the data series was rolled from the near contract into the next near contract ${ }^{20}$.

The values of the terms $k_{t}, m_{t}, n_{t}, D_{l}, D_{2}, D_{3 t}$ and $T_{t}$ in equation (11) are known with certainty, while estimates of $x, y, z$ and ${\sigma_{t-l}}^{2}$ are available ${ }^{21,22}$. The direction of the effect of announcements on volatility was examined by fitting equation $(12) \mathrm{using} \operatorname{GARCH}(1,1)$ and the quasi-maximum likelihood techniques of Bollerslev and Woodridge (1992).

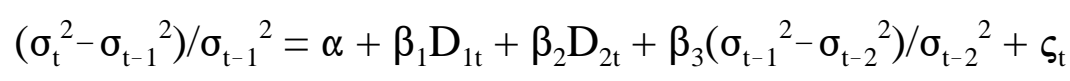


$D_{l t}$ and $D_{2 t}$ are dummies representing MPC and RPI announcements, and $\varsigma_{\mathrm{t}}$ is a disturbance term. The lagged dependent variable $(L D V)$ was included to deal with negative autocorrelation ${ }^{23}$. The results appear in table $3^{24}$. They show that on days with no announcement volatility rises by $1.09 \%$, on average; and so hypothesis 3 is confirmed. On days with an MPC announcement volatility falls by an average of (15.34-1.09) = $14.25 \%$, supporting hypothesis 4 . On days with an RPI announcement volatility falls by an average of $(5.66-1.09)=4.57 \%$, which is consistent with hypothesis 5 .

\title{
Coefficient z statistic Probabilit
}

\begin{tabular}{lrrr} 
& & \multicolumn{1}{c}{$\mathbf{y}$} \\
Constant $(\alpha)$ & $0.010876^{* *}$ & 2.631 & 0.0085 \\
MPC $\left(D_{l t}\right)$ & $-0.153411^{* *}$ & -5.137 & 0.0000 \\
RPI $\left(D_{2 t}\right)$ & $-0.056558^{* *}$ & -2.846 & 0.0044 \\
LDV & $-0.179500^{* *}$ & -5.090 & 0.0000
\end{tabular}

Conditional Variance Equation $((\mathrm{GARCH}(1,1))$

$\begin{array}{llll}\text { Constant }\left(\alpha_{0}\right) & 0.003755^{* *} & 2.793 & 0.0052 \\ \operatorname{ARCH}\left(\alpha_{1}\right) & 0.251335^{* *} & 4.480 & 0.0000 \\ \operatorname{GARCH}\left(\alpha_{2}\right) & 0.497213^{* *} & 4.327 & 0.0000\end{array}$

\section{Table 3: Average Effects of Two Types of Announcement on Volatility}

\begin{abstract}
Equation (12) was estimated using GARCH $(1,1)$ and the quasi-maximum likelihood techniques of Bollerslev and Woodridge (1992). The dependent variable is the proportionate change in the average anticipated volatility $\left(\sigma_{t}^{2}-\sigma_{t-1}{ }^{2}\right) / \sigma_{t-1}{ }^{2}$. The explanatory variables are dummy variables for MPC announcements $\left(D_{1 t}\right)$ and other scheduled announcements $\left(D_{2 t}\right)$, and the lagged dependent variable $(L D V)$. The constant term $(\alpha)$ represents no scheduled announcements. $* *=$ significantly different from zero at the $1 \%$ level, $*=$ significantly different from zero at the $5 \%$ level. Number of observations $=$ 675. Adjusted $\mathrm{R}^{2}=0.248$. $\mathrm{DW}=2.08$, Jarque-Bera $=37.34$.
\end{abstract}

Next the validity of the theory underlying equation (11), which specifies the size of the effect which different types of announcement have on the proportionate change in the average anticipated volatility, was investigated. Letting $\Upsilon_{t}=$ $-\left\{m_{t} x+k_{t} z\right\} D_{1 t} /\left[\sigma_{t-1}^{2}\left(T_{t}\left(T_{t}+1\right)\right], \quad \Omega_{t}=\left\{n_{t} z-m_{t} y\right\} D_{2 t} /\left[{\sigma_{t-1}}^{2}\left(T_{t}\left(T_{t}+1\right)\right] \quad\right.\right.$ and $\quad \Phi_{t}=$ $\left\{x n_{t}+y k_{t}\right\} D_{3 t} /\left[\sigma_{t-1}^{2}\left(T_{t}\left(T_{t}+1\right)\right]\right.$ and including a constant, a disturbance term and the lagged dependent variable, equation (11) becomes:-

$$
\left(\sigma_{\mathrm{t}}^{2}-\sigma_{\mathrm{t}-1}^{2}\right) / \sigma_{\mathrm{t}-1}{ }^{2}=\alpha+\beta_{1} \Upsilon_{\mathrm{t}}+\beta_{2} \Omega_{\mathrm{t}}+\beta_{3} \Phi_{\mathrm{t}}+\beta_{4}\left(\sigma_{\mathrm{t}-1}{ }^{2}-\sigma_{\mathrm{t}-2}{ }^{2}\right) / \sigma_{\mathrm{t}-2}{ }^{2}+\xi_{\mathrm{t}}
$$


Equation (13) was fitted to the data using $\operatorname{GARCH}(1,1)$ and the quasi-maximum likelihood techniques of Bollerslev and Woodridge (1992). The results are set out in table $4^{25}$.

\section{Coefficient z statistic Probabilit}

$\begin{array}{lcrc} & & & \mathbf{y} \\ \text { Constant } & -0.004740 & -0.809 & 0.4184 \\ \operatorname{MPC}\left(\Upsilon_{t}\right) & 1.900573^{*} & 2.080 & 0.0376 \\ \text { RPI }\left(\Omega_{t}\right) & 1.728491^{*} & 2.558 & 0.0105 \\ \text { None }\left(\Phi_{t}\right) & 3.438160^{* *} & 2.722 & 0.0065 \\ \text { LDV } & -0.185859^{* *} & -5.347 & 0.0000\end{array}$

Conditional Variance Equation $((\operatorname{GARCH}(1,1))$

$\begin{array}{llll}\text { Constant }\left(\alpha_{0}\right) & 0.003123^{*} & 2.093 & 0.0364 \\ \operatorname{ARCH}\left(\alpha_{1}\right) & 0.168483^{* *} & 3.949 & 0.0001 \\ \operatorname{GARCH}\left(\alpha_{2}\right) & 0.621469^{* *} & 5.575 & 0.0000\end{array}$

Table 4: Effect of Two Types of Scheduled Announcement on Volatility

Equation (13) was estimated using the quasi-maximum likelihood techniques of Bollerslev and Woodridge (1992). The dependent variable is the proportionate change

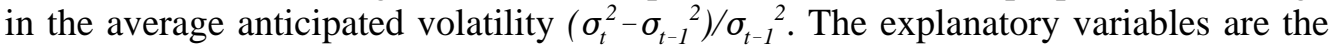
effect of MPC $\left(\Upsilon_{t}\right)$, other scheduled announcements $\left(\Omega_{t}\right)$, no scheduled announcements $\left(\Phi_{t}\right)$ and the lagged dependent variable $(L D V)$. ${ }^{* *}=$ significantly different from zero at the $1 \%$ level, $*=$ significantly different from zero at the $5 \%$ level. Number of observations $=675$. Adjusted $\mathrm{R}^{2}=0.223 . \mathrm{DW}=2.07$, Jarque-Bera $=113.47$.

If the theory in equation (11) is correct, the estimated regression coefficients $\left(\beta_{1}, \beta_{2}\right.$ and $\beta_{3}$ ) should be unity - hypothesis 6 . In addition, the constant term included in equation (13) $(\alpha)$ should be zero - hypothesis 7. As expected, the constant term is not significantly different from zero and hypothesis 7 is accepted. The estimated coefficients for MPC and RPI announcements are clearly not significantly different from one, suggesting that these announcements have a non-linear, time-varying effect on the implied volatility, as specified by $\Upsilon_{t}$ and $\Omega_{t}$. For non-announcement days, the estimated effect is not significantly different from one at the $5 \%$ level, which is also consistent with the theory that the implied volatility rises by $\Phi_{t}$ on non-announcement days. Therefore, hypothesis 6 is accepted.

\section{E. Implied Volatility and the Size of the Announcements}

The theoretical model ignores the size of the actual or surprise announcement, because it 
was assumed that the average anticipated volatility is independent of the size of current MPC and RPI surprises. This lack of dependence was tested by regressing the squared errors from equation (13) on MPC, $\xi_{t m}{ }^{2}$, and RPI, $\xi_{t p}{ }^{2}$, announcement days on the squared values of the unexpected changes in the repo rate and the RPI, i.e. $U \Delta M P C_{t}^{2}$ and $U \Delta R P I_{t}^{2}$. The independence assumption is supported if there is no connection between the size of the announcement surprises and the volatility errors - hypothesis 8 . Separate regressions were fitted for the MPC and RPI announcements, as specified in equations (14a) and (14b).

$$
\begin{gathered}
\xi_{\mathrm{tm}}^{2}=\alpha_{\mathrm{m}}+\beta_{\mathrm{m}} \mathrm{U} \Delta \mathrm{MPC}_{\mathrm{t}}^{2}+\mu_{\mathrm{tm}} \\
\xi_{\mathrm{tp}}{ }^{2}=\alpha_{\mathrm{p}}+\beta_{\mathrm{p}} \mathrm{U} \Delta \mathrm{RPI}_{\mathrm{t}}^{2}+\mu_{\mathrm{tp}}
\end{gathered}
$$

The results are contained in table $5^{26}$. They show no association between the squared volatility errors and the squared announcement surprises for either MPC or RPI announcements, supporting the independence assumption made above.

\title{
Coefficient t statistic Probabilit
}

Equation (14b) MPC

$\begin{array}{lrrr}\text { Constant }\left(\alpha_{m}\right) & 0.046291^{* *} & 3.014 & 0.0053 \\ \mathrm{U} \Delta \mathrm{MPC}_{\mathrm{t}}^{2}\left(\beta_{m}\right) & -0.298475 & -0.665 & 0.5111 \\ \text { Equation }(14 b) R P I & & \\ \text { Constant }\left(\alpha_{p}\right) & 0.016393^{* *} & 3.536 & 0.0013 \\ \mathrm{U}_{\Delta \mathrm{RPI}_{\mathrm{t}}{ }^{2}\left(\beta_{p}\right)} & 0.078211 & 0.400 & 0.6919\end{array}$

\section{Table 5: Announcement Surprises and Volatility Errors}

\begin{abstract}
Equations (14a) and (14b) were estimated using ordinary least squares. The dependent variable is the squared error from equation (13) on either MPC or RPI announcement days. The explanatory variable is the squared surprise in either the MPC or RPI announcement. $* *=$ significantly different from zero at the $1 \%$ level, $*=$ significantly different from zero at the 5\% level. For equation (14a): number of observations $=31$, adjusted $R^{2}=-0.019$, Jarque-Bera $=42.88$. For equation (14b): number of observations $=32$, adjusted $\mathrm{R}^{2}=-0.028$, Jarque-Bera $=11.93$.
\end{abstract}

Regressions where the variables in equation (14) are not squared or unsigned also find no significant relationships. This indicates that including the size of the announcement surprises in equation (13) would not improve the fit, and supports the theoretical model 
which argues that the volatility is affected by the announcement event, and not by its content.

\section{Conclusions}

The impact of the scheduled MPC and other macroeconomic announcements was traced through the spot, futures and options markets in UK short term interest rates. It was found that both the spot and futures markets react strongly to surprises in the repo rate and the RPI, and that price volatility rises on these days. The response of these two markets to repo rate surprise announcements by the MPC is asymmetric, with a bigger reaction for positive surprises; and the response co-efficient is usually less than unity. This apparent under-response may be because the expected change in the repo rate is now expected at either of the next two MPC meetings, or because expectations become more accurate in the seven days between being observed and the MPC meeting.

Since surprise repo rate and RPI announcements have a powerful influence on the spot and futures markets, they should also affect the market for options on short term interest rates. A key determinant of the options price is the expected volatility of returns on the underlying asset. Because the repo rate and RPI announcements are scheduled, the options market can predict the days on which announcement shocks may hit and build this information into its volatility expectations. A theoretical model was constructed which states that the volatility used in pricing options alters over time in a predictable non-linear manner that varies with contract maturity and the number of forthcoming announcements, but is independent of the size of the announcement. The data reveals that MPC announcements lead to a substantial decrease in the implied volatility, RPI announcements result in a smaller decrease, and no scheduled announcement is associated with a small increase in the implied volatility. The data is consistent with the response coefficients of the theoretical model.

The model developed in this paper explains why options that differ only in their expiry 
date have different implied volatilities (i.e. the volatility term structure). Since the implied volatility depends on the number of announcements scheduled to occur before expiry, the implied volatility will generally be higher for contracts with a longer period until expiry.

This paper is a test of semi-strong market efficiency for the UK spot, futures and options markets in short term interest rates. The reactions of the spot and futures markets are fully consistent with semi-strong efficiency. It was found that, even if the volatility of the underlying asset is unpredictable, the implied volatility of Short Sterling options is predictable. While this means that movements in the implied volatility (and hence options prices) are predictable, it does not conflict with semi-strong efficiency because there are sound economic reasons for these patterns in implied volatility. Indeed, if the implied volatility did not move in the predictable manner required by the scheduled announcements, there would be a conflict with semi-strong efficiency.

\section{End Notes}

1. A repo or "sale and repurchase agreement" can apply to Sterling treasury bills, UK government foreign currency debt, eligible bank and local authority bills, certain Sterling bonds issued by supranational organizations and by governments in the European Economic Area, (Monetary Policy Committee, 1999).

2. The use of changes facilitates the interpretation of the coefficients from the regression as the explanatory variables are also changes.

3. An unexpected increase in the repo rate is defined as the announced repo rate exceeding the expected repo rate.

4. The data period was $1^{\text {st }}$ May 1997 to $31^{\text {st }}$ December 1999 . The daily LIBOR rates came from DataStream, while the actual and expected monthly macroeconomic announcements were taken from Standard and Poor's Money Market Services. Expectations are generally surveyed one to two weeks before the expected announcement. The expected changes in the repo rate were supplied by Reuters, who conduct a monthly survey of the expectations of about 30 financial institutions on the Thursday of the week before the scheduled MPC meeting. For each month the mean forecast change in the variable was subtracted from the actual change, to give a measure of the surprise. The meting dates of the MPC were supplied by the Bank of England.

5. For LIBOR, this refers to the next three months. For Short Sterling futures, this assumption covers the next 3 to 6 months, depending on the maturity of the contract.

6. Five days with very large errors were dummied out of this regression. These are $3^{\text {rd }}$ July 1997 (UK budget), 28 $8^{\text {th }}$ August 1998, 16 ${ }^{\text {th }}$ October 1998 (unexpected cut in US interest rates), $4^{\text {th }}$ December 1998 and $1^{\text {st }}$ October 1999 (purchasing manager survey). 
7. Suppose that, immediately before the MPC announcement, the market expects the MPC to raise the repo rate from $4 \%$ to $5 \%$ at their next meeting and keep it there for at least the two subsequent meetings. However, the MPC announces no change, and so there is a $1 \%$ surprise. The market now expects the repo rate to be raised by $1 \%$ at either the next MPC meeting, or the one after that. If these two possible outcomes are thought to be equally likely, the LIBOR rate for the next three months following the failure of the MPC to raise the repo rate at their current meeting is approximately $[(4 \%+5 \%+5 \%) / 3+(4 \%+4 \%+5 \%) / 3] / 2=4.5 \%$. In which case a $1 \%$ surprise in the repo rate (due to the MPC not raising the repo rate by $1 \%$ at their current meeting) leads to only a $0.5 \%$ drop in LIBOR from $5 \%$ to $4.5 \%$.

8. This interest rate became the repo rate set by the MPC.

9. Changes in the current spot rate will directly alter the no-arbitrage price of Short Sterling futures. Let the annual rate of return from lending money from now until three months after the maturity of the Short Sterling future be $R_{L}$ (the long rate), the annual future spot return implicit in the current price of the Short Sterling future be $R_{F}$, and the annual rate of return from lending money between now and the maturity of the futures contract be $R_{S}$ (the short rate). In a noarbitrage world, adjusted for the length of the holding periods, the return from using the long rate must be the same as that from using the short rate and a Short Sterling future. By convention, the price of Short Sterling futures is quoted as $100.00\left(1-R_{F}\right)$ and so the no-arbitrage price $(F)$ is given by

$$
F=100\left\{2-[L / S]^{365 / n}\right\}
$$

where $S=\left(1+R_{S}\right)^{T / 365}, L=\left(1+R_{L}\right)^{(T+n) / 365}$, $T$ is the number of days to the maturity of the futures contract and $n$ is 3 months. The above equation shows that the no-arbitrage price of Short Sterling futures is affected by changes in the ratio of $R_{L}$ to $R_{S}$. Both these variables are directly affected by the repo rate.

10. Since interest rates are altered with a tick size of 25 basis points, which exceeds arbitrage transactions costs, the MPC announcements are generally expected to have an immediate effect on the price of Short Sterling futures.

\section{The daily closing futures prices were supplied by LIFFE.}

12. By convention interest rate futures prices are quoted as $100.00\left(1-R_{F}\right)$, where $R_{F}$ is the annual future spot return implicit in the current price of the Short Sterling future. Therefore, an increase in $R_{F}$ of $1 \%$ corresponds to a decrease in $F$ of $1 \%$, and so the repo rate is expected to have a negative effect on the futures' price.

13. Five days with very large errors were dummied out of this regression. These are $27^{\text {th }}$ and $28^{\text {th }}$ August 1998, 16 ${ }^{\text {th }}$ October 1998 (unexpected cut in US interest rates), $3^{\text {th }}$ December 1998 and $2^{\text {nd }}$ March 1999 (relaunch of the earnings series after previous errors).

14. The scheduled announcements make volatility a function of time.

15. The term "implied volatility" will be used to refer to the variance implied by the options price, not the standard deviation.

16. This figure is drawn using the coefficients derived below in equation (13) and the variances estimated as described in endnote 22.

17.This assumption is examined in section 3.E when hypothesis 8 is tested. It is assumed that the sizes of the three types of anticipated volatility $\left(\sigma_{n a}{ }^{2}, \sigma_{a}^{2}\right.$ and $\left.\sigma_{b}^{2}\right)$ are constant over time. 
18. For simplicity, it is assumed that MPC and other scheduled announcements do not occur on the same day.

19. A simple numeric example illustrates this possibility of a perverse market reaction to the resolution of uncertainty. Let $k_{t}=5, m_{t}=1, n_{t}=4, \sigma_{n a}{ }^{2}=1, \sigma_{a}{ }^{2}=5, \sigma_{b}{ }^{2}=10$. Then $\sigma_{t-1}{ }^{2}=\left(m_{t} \sigma_{n a}{ }^{2}\right.$ $\left.+k_{t} \sigma_{b}^{2}+\left(n_{t}+1\right) \sigma_{a}^{2}\right) /\left(T_{t}+1\right)=(1+50+25) / 11=6.91, Y_{1 t}=m_{t} /\left[\sigma_{t-1}{ }^{2}\left(T_{t}\left(T_{t}+1\right)\right]=1 /[6.91(110)]=\right.$ $0.0013156, Y_{2 t}=k /\left[\sigma_{t-1}{ }^{2}\left(T_{t}\left(T_{t}+1\right)\right]=5 /\left[6.91(110)=0.006578, \phi=\left(\sigma_{n a}{ }^{2}-\sigma_{a}{ }^{2}\right)=(1-5)=-4\right.\right.$ and $\eta=\left(\sigma_{b}^{2}-\sigma_{a}{ }^{2}\right)=10-5=5$. Therefore, $\phi Y_{1 t}+\eta Y_{2 t}=-4(0.0013156)+5(0.006578)=+0.02763$.

20. As the contract nears expiry, volume drops and stale prices become more prevalent. This biases the estimates of the implied volatility. In addition, as the option nears expiry and its price becomes smaller, the tick size becomes more important, leading to unreliable results, Patel and Wolfson (1981).

21. The implied volatilities were computed in the way described above.

22.The values of $\sigma_{n a}{ }^{2}, \sigma_{a}^{2}$ and $\sigma_{b}^{2}$ (on which $x, y$ and $z$ depend) were estimated using the errors from fitting equation (2), but with $r_{t}=\ln \left[\left(100-F_{t}\right) /\left(100-F_{t-1}\right)\right]$ as the dependent variable, rather than $\Delta F_{t}$. Logarithmic returns were used as the dependent variable so that the error terms could be used to estimate the variance of the yield, as required by equation (3). The conclusions from fitting this equation are the same as for equation (2). These errors were partitioned into three non-overlapping subsets: MPC announcement, RPI announcement and no announcement days. The average volatilities were then computed for each subset. The values of ${\sigma_{t-1}}^{2}$ are simply the lagged daily implied volatilities.

23. Since $\sigma_{t-1}$ appears in both the dependent and explanatory variables, any measurement error will result in negative autocorrelation. Ederington and Lee (1996) included the lagged dependent variable to control for negative autocorrelation when they estimated their version of equation (12).

24. The observations for $20^{\text {th }}$ May $1997,9^{\text {th }}$ July $1997,21^{\text {st }}$ August $1997,21^{\text {st }}$ August $1998,27^{\text {th }}$ August 1998, $28^{\text {th }}$ August 1998, and $15^{\text {th }}$ January 1999 were dummied out.

25. The observations mentioned in endnote 24 were dummied out.

26. Regressions of the same form as equation (14) but using absolute values also find no relationship.

\section{References}

Anderson, R.W. and Danthine, J.P. (1983) The time pattern of hedging and the volatility of futures prices, Review of Economic Studies, vol. 50(2), no. 161, pp. 249-266.

Bailey, W. (1988) Money supply announcements and the ex ante volatility of asset prices, Journal of Money, Credit and Banking, vol. 20, no. 4, November, pp. 611-620.

Barone-Adesi, G., Brown, K.C. and Harlow, W.V. (1994) On the use of implied volatilities in the prediction of successful corporate takeovers. In Advances in Futures and Options Research, vol. 7, edited by D.M. Chance and R.R. Trippi, JAI Press, pp. 147-165.

Black, F. (1976) The pricing of commodity contracts, Journal of Financial Economics, vol. 3, nos. 1-2, January-March, pp. 167-179.

Black, F. and Scholes, M. (1973) The pricing of options and corporate liabilities, Journal of Political Economy, vol. 81, no. 3, pp. 637-659. 
Bollerslev, T. and Woodridge, J.M. (1992) Quasi-maximum likelihood estimation and inference in dynamic models with time-varying covariances, Econometric Reviews, vol. 11, no. 2, pp. 143-172.

Bomfim, A.N. and Reinhart, V.R. (2000) Making news: financial market effects of Federal Reserve disclosure practices, Working Paper, Federal Reserve Board, Washington D.C., March, 36 pages.

Bonser-Neal, C. (1996) Does central bank intervention stabilize foreign exchange rates?, Economic Review of the Federal Reserve Bank of Kansas City, First Quarter, pp. 43-57.

Bonser-Neal, C. and Tanner, G. (1996) Central bank intervention and the volatility of foreign exchange rates: evidence from the options market, Journal of International Money and Finance, vol. 15, no. 6, December, pp. 853-878.

Buckle, M., ap Gwilym, O., Thomas, S.T. and Woodhams, M.S. (1998) Intraday empirical regularities in interest rate and equity index futures markets, and the effect of macroeconomic announcements, Journal of Business Finance and Accounting, vol. 25, no. 7, September-October, pp. 921-944.

Budd, A. (1998) The role and operations of the Bank of England Monetary Policy Committee, Economic Journal, vol. 108, no. 451, November, pp. 1783-1794.

Chen, R.R. and Scott, L. (1993) Pricing interest rate futures options with futures style margining, Journal of Futures Markets, vol. 13, no. 1, February, pp. 15-22.

Copeland, L., Poon, S.H. and Stapleton, R.C. (2000) The determinants of implied volatility: a test using LIFFE option data, Journal of Business Finance and Accounting, vol. 27, nos 7\&8, September-October, pp. 859-885.

Cornell, B. (1978) Using the option pricing model to measure the uncertainty producing effect of major announcements, Financial Management, vol. 7, no. 1, Spring, pp. 54-59.

Corrado, C.J. and Miller, T.W. (1996) Efficient option-implied volatility estimators, Journal of Futures Markets, vol. 16, no. 3, May, pp. 247-272.

Donders, M.W.M. and Vorst, T.C.F. (1996) The impact of firm specific news on implied volatilities, Journal of Banking and Finance, vol. 20, no. 7, November, pp. 14471461.

Ederington, L.H. and Lee, J.H. (1996) The creation and resolution of market uncertainty: the impact of information releases on implied volatility, Journal of Financial and Quantitative Analysis, vol. 31, no. 4, December, pp. 513-539.

Engle, R. (1982) Autoregressive conditional heteroskedasticity with estimates of the variance of UK inflation, Econometrica, vol. 50, no. 4, July, pp. 987-1008.

French, D.W. (1984) The weekend effect on the distribution of stock prices: implications for option pricing, Journal of Financial Economics, vol. 13, no. 4, September, pp. 547-559.

French, D.W. and Dubofsky, D.A. (1986) Stock splits and implied stock price volatility, Journal of Portfolio Management, vol. 12, no. 4, Summer, pp. 55-59.

French, D.W. and Fraser, D.R. (1986) A note on interest rates and the risk of bank and savings and loan stock, Financial Review, vol. 21, no. 4, November, pp. 551-558.

Gemmill, G. (1992) Political risk and market efficiency: tests based in British stock and options markets in the 1987 election, Journal of Banking and Finance, vol. 16, no. 1, February, pp. 211-231.

Heynen, R., Kemna, A. and Vorst, T. (1994) Analysis of the term structure of implied volatilities, Journal of Financial and Quantitative Analysis, vol. 29, no. 1, March, 
pp. 31-56.

Hull, J, and White, A. (1987) The pricing of options on assets with stochastic volatilities, Journal of Finance, vol. 42, no. 2, June, pp. 281-300.

Jayaraman, N., Mandelker, G. and Shastri, K. (1991) Market anticipation of merger activities: an empirical test, Managerial and Decision Economics, vol. 12, no. 6, December, pp. 439-448.

Jayaraman, N. and Shastri, K. (1993) The effects of the announcements of dividend increases on stock return volatility; the evidence from the options market, Journal of Business Finance and Accounting, vol. 20, no. 5, September, pp. 673-685.

Jones, C.M., Lamont, O. and Lumsdaine, R.L. (1998) Macroeconomic news and bond market volatility, Journal of Financial Economics, vol 47, no. 3, March, pp. 315337

Klein, L.S. and Peterson, D.R. (1988) Investor expectations of volatility increases around large stock splits as implied in call option premia, Journal of Financial Research, vol. 11, no. 1, Spring, pp. 71-80.

Kuttner, K.N. (2000) Monetary policy surprises and interest rates: evidence from the Fed funds futures market, Working Paper, Federal Reserve Bank of New York, February, 22 pages.

Levy, H. and Yoder, J.A. (1993) The behaviour of option implied standard deviations around merger and acquisition announcements, Financial Review, vol. 28, no. 2, May, pp. 261-272.

Li, L. and Engle, R.F. (1998) Macroeconomic announcements and volatility in Treasury futures, Discussion Paper no. 98-27, Economics Department, University of California, San Diego, November 1998

Madura, J. and Tucker, A.L. (1992) Trade deficit surprises and the ex ante volatility of foreign exchange rates, Journal of International Money and Finance, vol. 11, no. 5, October, pp. 492-501.

Merton, R.C. (1973) The theory of rational option pricing, Bell Journal of Economics and Management Science, vol. 4, no, 1, Spring, pp. 141-183.

Monetary Policy Committee. (1999) The transmission mechanism of monetary policy, Bank of England, April, 12 pages.

Patell, J.M. and Wolfson, M.A. (1979) Anticipated information releases reflected in call option prices, Journal of Accounting and Economics, vol. 1, no. 2, August, pp. 117-140.

Patell, J.M. and Wolfson, M.A. (1981) The ex ante and ex post price effects of quarterly earnings announcements reflected in option and stock prices, Journal of Accounting Research, vol. 19, no. 2, Autumn, pp. 434-458.

Samuelson, P.A. (1965) Proof that properly anticipated prices fluctuate randomly, Industrial Management Review, vol. 6, Spring, pp. 41-49.

Sheikh, A.M. (1989) Stock splits, volatility increases and implied volatilities, Journal of Finance, vol. 44, no. 5, December, pp. 1361-1372.

Slovin, M.B., Sushka, M.E. and Waller, E.R. (1994) Is there news in the prime rate?, Journal of Financial and Quantitative Analysis, vol. 29, no. 4, December, pp. 633646.

Tucker, A.L. and Madura, J. (1991) Impact of the Louvre Accord on actual and anticipated exchange rate volatilities, Journal of International Financial Markets, Institutions and Money, vol. 1, no. 2, pp. 43-59. 
